\title{
A cost-benefit analysis of the Working for Water Programme on selected sites in South Africa
}

\author{
SG Hosking* and M du Preez \\ Department of Economics and Economic History, University of Port Elizabeth, PO Box 1600, Port Elizabeth 6000, South Africa
}

\begin{abstract}
The Working for Water Programme entails the removal of water-consuming alien vegetation and the restoration of low waterconsuming indigenous vegetation. It was implemented in 1995 to address the management of catchment areas in South Africa. The question of this programme's economic feasibility in the Western Cape and in KwaZulu-Natal has been addressed by various authors. This paper addresses its feasibility in the Eastern Cape Province and regions of the southern Cape. Cost-benefit analyses are carried out on six sites: Tsitsikamma, Kouga, Port Elizabeth Driftsands, Albany, Kat River and Pott River. It is shown that catchment management on all the sites carried out by the Working for Water Programme is inefficient.

This conclusion is subject to three qualifications. The first is that more work remains to be done on the evaluation of the nonwater benefits. Known non-water benefits, like fire damage reduction and preservation of biodiversity were not included in the calculations. The second qualification is that at lower discount rates, for instance $5 \%$, the Kouga project is efficient. The third qualification is that if $30 \%$ cost savings could be achieved and a discount rate of $5 \%$ be employed, both the projects on the Kouga and Tsitsikamma sites will become efficient. These two projects are being run in catchments which serve areas where high consumptive demand exists.
\end{abstract}

Keywords: alien vegetation, non-water benefits, marginal costs, mountain catchment management, social discount rate, water yield, livestock

\section{Introduction}

The Working for Water Programme is the single biggest conservation project in South Africa in terms of manpower and impact (Hosking et al., 2002). In 1998 there were 260000 people in South Africa were employed on it (Hosking et al., 2002). The Programme entails removing alien vegetation from selected areas and restoring indigenous vegetation there. Costs and benefits are incurred in this process. The benefits include increasing streamflow, increasing livestock carrying capacity, reducing fire hazard damage and preserving biodiversity.

Initially most of the work on the Programme conducted in the Eastern and Southern Cape was in the Tsitsikamma Mountains. More recently attention has been directed toward the coastal region, mainly in the Port Elizabeth and Port Alfred areas. The biggest urban undertaking by the Working for Water Programme is in the Port Elizabeth area, where 2050 people were employed in 1999 (Buckle, 1999).

The economic rationale underlying the Programme in selected mountain catchments in the Western Cape was presented by Van Wilgen et al. (1997) and Marais (1998). A cost-benefit analysis of the Working for Water Programme in the Mgeni cathcment in KwaZulu-Natal was conducted by Gillham and Haynes (2001). Their analyses concluded that the programme was efficient.

Some cost-benefit analysis was also done in the Eastern Cape (Hosking and Du Preez, 1999), but not much. This study aims to fill this gap: the relevant costs and benefits are estimated and com-

* To whom all correspondence should be addressed.

푱+2741 504-2638; fax:+2741 5832644; e-mail: ecasgh@upe.ac.za Received 17 September 2003.

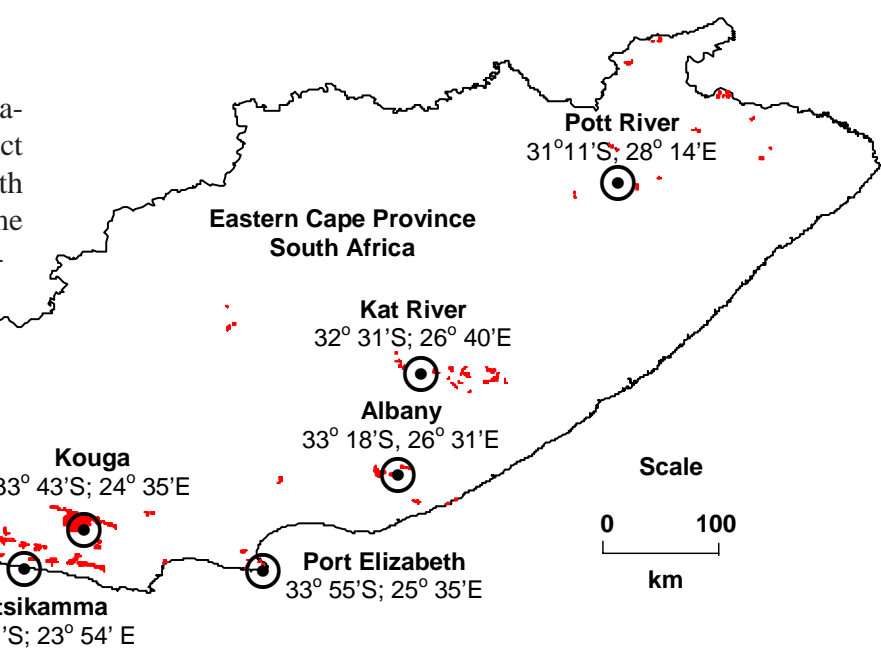

Location of the six Working for Water Programme projects

pared at six sites in the Eastern and Southern Cape: those on the Tsitsikamma, Kouga, Port Elizabeth Driftsands, Albany, Kat River and Pott River sites (Fig. 1).

\section{The study area}

Site selection for this study was made with the aim of including as diverse a range of sites as possible. In this regard, inter alia, reference to topography, indigenous and alien vegetation present was taken into account. Brief background information on the six sites selected is presented in Table 1 . 


\begin{tabular}{|l|c|c|c|c|c|c|c|c|c|}
\hline \multicolumn{7}{|c|}{ Background information on the six Working for Water sites } \\
\hline Catchment & $\begin{array}{c}\text { Area of } \\
\text { Working } \\
\text { for Water } \\
\text { control } \\
\text { (ha) }\end{array}$ & $\begin{array}{c}\text { Mean } \\
\text { annual } \\
\text { rainfall } \\
\text { (mmy } \text { (MAP) }^{\text {(MAn) }}\end{array}$ & $\begin{array}{c}\text { Mean } \\
\text { annual } \\
\text { runoff } \\
\text { (mm) } \\
\text { (MAR) }\end{array}$ & $\begin{array}{c}\text { Fire } \\
\text { fre- } \\
\text { quency } \\
\text { (years) }\end{array}$ & $\begin{array}{c}\text { Fire } \\
\text { cycle } \\
\text { (years) }\end{array}$ & $\begin{array}{c}\text { Post- } \\
\text { fire } \\
\text { age } \\
\text { (years) }\end{array}$ & $\begin{array}{c}\text { Indi- } \\
\text { genous } \\
\text { vegetation }\end{array}$ & $\begin{array}{c}\text { Dominant } \\
\text { exotic } \\
\text { vegetation }\end{array}$ & $\begin{array}{c}\text { Rate } \\
\text { of } \\
\text { spread } \\
\text { (\%) }{ }^{-1} \text { ) }\end{array}$ \\
\hline Tsitsikamma & 128783 & 960 & 342 & 10 & 12 & $1-12$ & $\begin{array}{c}\text { Mountain } \\
\text { fynbos }\end{array}$ & $\begin{array}{c}\text { Acacia spp.; } \\
\text { Pinus spp. }\end{array}$ & 5.5 \\
\hline Kouga & 158678 & 547 & 255 & $8-15$ & 12 & $1-12$ & $\begin{array}{c}\text { Grassy } \\
\text { fynbos }\end{array}$ & $\begin{array}{c}\text { Acacia spp.; } \\
\text { Pinus spp; } \\
\text { Hakea spp. }\end{array}$ & 15 \\
\hline Albany & 11400 & 650 & 113 & 3 & 4 & 20 & $\begin{array}{c}\text { Grassy } \\
\text { fynbos; } \\
\text { valley } \\
\text { bushveld }\end{array}$ & $\begin{array}{c}\text { Acacia spp.; } \\
\text { Hakea spp. }\end{array}$ & 5.5 \\
\hline Port Elizabeth Driftsands & 8700 & 490 & 229 & 4 & 12 & $1-12$ & $\begin{array}{c}\text { Grassy } \\
\text { fynbos }\end{array}$ & Acacia spp. & 2 \\
\hline Kat River & 1196 & 950 & 335 & 3 & 4 & 20 & $\begin{array}{c}\text { Moist } \\
\text { upland } \\
\text { grassland }\end{array}$ & $\begin{array}{l}\text { Acacia spp.; } \\
\text { Pinus spp. }\end{array}$ & 2.5 \\
\hline Pott River & 490 & 939 & 327 & 2 & 4 & 20 & $\begin{array}{c}\text { South- } \\
\text { Eastern } \\
\text { mountain } \\
\text { grassland }\end{array}$ & $\begin{array}{l}\text { Acacia spp.; } \\
\text { Populus spp. }\end{array}$ & 13 \\
\hline
\end{tabular}

\section{Nature of the Working for Water Programme}

Exotic invasive plants have been shown to severely affect mountain catchment areas by displacing indigenous vegetation and substantially reducing surface runoff (Van Wilgen et al., 1990; Le Maitre et al., 1996; Van Wilgen et al., 1996). Alien plant and tree infestations consume more water than indigenous vegetation. The invader plants and trees are generally taller, faster growing, evergreen, adapted to optimise water consumption, and possess a high reproductive capacity (Briers and Powell, 1993), especially when compared to the indigenous fynbos and grassveld that occur in most of the mountain catchments in the Eastern and Southern Cape. Improving the water yield from catchment areas through the clearing of alien trees and the restoration of low water-consuming indigenous vegetation is the primary rationale for the implementation of the Working for Water Programme.

The control of plant invaders entails their removal in places where they have established themselves and in areas where infestation is at its initial stages. The areas are divided into management units, ranging in size from approximately 50 to 2000 ha (in some areas management units are in excess of $7000 \mathrm{ha}$ ). Objectives are set for each such unit, and records kept for all management operations. The spread of alien vegetation is controlled through concentrated efforts of initial clearing of units and repeated followup procedures. Initial clearing entails the removal of alien vegetation, whereas follow-up operations entail the removal of the regrowth of alien vegetation in a previously cleared area. Follow-up operations in areas that have already been cleared normally take priority in field operations because if re-growth is allowed to occur the initial investment is wasted. Two initial follow-ups are normally carried out after initial clearing, each in consecutive years. Maintenance management is conducted for two to five years thereafter. The eradication methods include manual, mechanical, chemical and biocontrol techniques. Control programmes differ depending on the species, the density of the stands and the accessibility of the management units.

\section{Cost-benefit analysis}

Cost-benefit analysis (CBA) is a standard method of comparing the social costs and benefits of alternative projects or investments. Costs and benefits are measured and then weighed up against each other in order to generate criteria for decision-making. Typically one or more of three decision criteria are used:

\section{- $\quad$ Net present value (NPV) \\ - Internal rate of return (IRR) \\ - Benefit-cost ratio (BCR).}

A project is deemed to be acceptable if the NPV is positive, or the IRR exceeds the applicable discount rate, or the BCR exceeds unity.

There are four basic elements to CBA - time considerations, costs, benefits and the social discount rate. All of these are discussed below. 
TABLE 2

Cost of clearing, follow-up operations and maintenance for six different project sites*+

\begin{tabular}{|c|c|c|c|c|c|c|}
\hline Treatment & $\begin{array}{l}\text { Tsitsi- } \\
\text { kamma } \\
\text { (R/ha) }\end{array}$ & $\begin{array}{l}\text { Kouga } \\
\text { (R/ha) }\end{array}$ & $\begin{array}{l}\text { Port } \\
\text { Elizabeth } \\
\text { Driftsands } \\
\text { (R/ha) }\end{array}$ & $\begin{array}{l}\text { Albany } \\
\text { (R/ha) }\end{array}$ & $\begin{array}{l}\text { Kat } \\
\text { River } \\
\text { (R/ha) }\end{array}$ & $\begin{array}{l}\text { Pott } \\
\text { River } \\
\text { (R/ha) }\end{array}$ \\
\hline Initial (clearing) & 1236 & 2300 & 2650 & 2440 & 1440 & 1435 \\
\hline $1^{\text {st }}$ follow-up & 400 & 400 & 700 & 750 & 840 & 1100 \\
\hline $2^{\text {nd }}$ follow-up & 248 & 200 & 400 & 360 & 450 & 700 \\
\hline Maintenance (1 $1^{\text {st }}$ year $)$ & 140 & 50 & 200 & 170 & 255 & 100 \\
\hline Maintenance ( $2^{\text {nd }}$ year) & 65 & 20 & 70 & 140 & 110 & 50 \\
\hline Maintenance ( $3^{\text {rd }}$ year) & 25 & 20 & 20 & 70 & 60 & 0 \\
\hline Maintenance ( $4^{\text {th }}$ year) & 15 & 20 & 20 & 60 & 0 & 0 \\
\hline Maintenance ( $5^{\text {th }}$ year) & 0 & 20 & 20 & 50 & 20 & 30 \\
\hline Maintenance ( $6^{\text {th }}$ year) & 15 & 0 & 20 & 20 & 0 & 0 \\
\hline Maintenance ( $7^{\text {th }}$ year) & 0 & 0 & 0 & 20 & 20 & 0 \\
\hline Maintenance ( $8^{\text {th }}$ year) & 15 & 0 & 0 & 20 & 0 & 30 \\
\hline \multicolumn{7}{|c|}{$\begin{array}{l}\text { (Source: Hosking et al., 2002). } \\
\text { * The costs presented in Table } 2 \text { were provided by individual project managers and represent the average costs for all } \\
\text { density classes } \\
+\quad \text { Management costs are included }\end{array}$} \\
\hline
\end{tabular}

\section{Time considerations}

All estimated cost and benefit flows derived in this investigation are captured in per annum periods and expressed at 2000 price levels. A distributional weighting of one was used for all crosssectional costs and benefits over the full project period. This weighting assumes that a rand benefit is worth the same to all members of the population affected by the projects in question. The project period or time horizon of the project was set at 100 years.

\section{The cost of clearing alien plants}

Cost information was obtained from the project managers of the selected initiatives of the Working for Water Programme in the Eastern and Southern Cape.

\section{Primary costs}

The primary costs associated with the Working for Water Programme are those for capital equipment (chain saws, vehicles, tools and computers), herbicides (herbicides, diesel, dyes and wetters), protective clothing (gloves, masks, overalls, boots and helmets), wages and salaries, transport (including subsidised transport and repairs), clearing work contracted out to private institutions, and running expenses, including machinery running expenses (filters and replacement parts), fuels and oils, and stationery, printing and telephone expenses. The acquisition of equipment is an investment cost, whereas the other costs mentioned are operating costs. The costs were expressed in R/ha and were based on the actual costs (key performance indicator [KPI] reports were used as a basis) incurred since the inception of the various projects, as well as projections made by the various project managers.

The Working for Water Programme is a labour-intensive public works programme. Salaries and wages thus constitute a large portion of overall costs attributable to the project. As this programme is aimed at uplifting marginalised communities in areas where high unemployment exists, the question arises as to how labour should be valued. Three options were considered - the normal market wage for unskilled labour, the wage paid by the Working for Water Programme and the shadow price of this labour. Given the existence of unemployment at the selected sites it was deduced that the shadow price would be relevant, i.e. the subsistence wage or the minimum required to induce the workers into employment. It was further observed that the subsistence wage would be well below the market wage. However, it was not at all clear that it would be below the wage actually paid by the Working for Water Programme, as this rate is also well below the market wage. Accordingly it was assumed that the Working for Water wage would be the shadow wage rate and this was used in the CBA.

Regarding the overall costs of the Working for Water Programme two alternative views exist. The first view is that one is dealing with real costs since this is a paying project (the view taken in this study). The second view pertains to the fact that the Working for Water Programme is a poverty relief project and hence the costs incurred should be treated as transfer payments instead of real costs. This view was rejected on the basis that the Working for Water Programme, like any other public works programme initiated by the government, was competing for limited funding Hence the economic feasibility of this programme had to be examined using real costs and benefits to establish whether it should enjoy preference above other government programmes. The primary costs are shown in Table 2.

\section{Secondary costs}

In addition to the above-mentioned primary costs, a reduction in the availability of alien tree species as a source of firewood is a secondary cost (Buckle, 1999). Marais (1998) argued that this cost could be reduced by encouraging small local industries to supply the community with alternative sources of firewood from indigenous sources. 
The benefits of clearing alien plants on six Working for Water Programme project sites

The benefits of the Working for Water Programme were divided into primary benefits and secondary benefits. The most important primary benefit is increased water yield $\left(\mathrm{m}^{3} / \mathrm{ha} \cdot \mathrm{a}\right)$.

Secondary benefits associated with the programme include conservation and maintenance of biodiversity nurseries, improvement in water quality, secondary wood industry stimulation, training, poverty alleviation, reduction of flood and fire damage (and soil erosion), improved tourism attractiveness and increased yield of agricultural products.

\section{Primary benefit estimates}

The estimates of the primary benefit of increased water yield in $\mathrm{m}^{3} / \mathrm{ha}$ per fire cycle are shown in Table 3. Increased water yield was determined by applying a model that generated estimates of streamflow on a yearly basis for a simulation of 10 years, for situations where alien trees and plants are present or absent. In this model streamflow reduction with aliens was estimated using modelling of Versveld et al. (1998) with the addition of a "rate of spread" component as suggested in Le Maitre et al. (1996).

According to the model of Versveld et al. (1998), estimates of biomass are converted into estimates of streamflow reduction in millimetre rainfall equivalents. The model takes the following form:

$$
\text { Streamflow reduction }(\mathrm{mm})=0.0238 \mathrm{~B}
$$

where:

$\mathrm{B}=$ standing biomass of exotic invading plants $\left(\mathrm{g} \cdot \mathrm{m}^{-2}\right)$.

B was estimated by calculating the additional biomass of alien invasive plants as a function of their cover and age since the last fire, using the numerical growth form models developed by Le Maitre et al. (1996) of three biomass classes, namely tall shrub, medium tree and tall tree. The biomasses of the different species were then summed to give the standing biomass (B) of exotics in the catchment. The area of infestation (post-fire cover) at the six selected Working for Water Programme sites in the Eastern and Southern Cape was estimated and a density class allocated to it from information supplied by the respective project managers of these sites.

The post-fire age (in years) and the rate of spread for the six sites are shown in Table 1.

Streamflow reduction without aliens was estimated using Chapman et al.’s (1995) modelling. The predictive equation for runoff under conditions of minimum vegetation cover is as follows:

$$
\text { MAR }=0.74 \text { MAP }-368
$$

where:

MAR $=$ mean annual runoff $(\mathrm{mm} / \mathrm{a})$

MAP $=$ mean annual precipitation $(\mathrm{mm} / \mathrm{a})$.

The figures for MAR and MAP for the six sites are shown in Table 1 . It must be noted that this benefit stream only accrues once
TABLE 3

yield $\left(\mathrm{m}^{3} / \mathrm{ha}\right)$ per fire cycle for the six

\begin{tabular}{|c|c|c|c|}
\hline $\begin{array}{c}\text { Port } \\
\text { Elizabeth } \\
\text { Driftsands }\end{array}$ & Albany & $\begin{array}{c}\text { Kat } \\
\text { River }\end{array}$ & $\begin{array}{l}\text { Pott } \\
\text { River }\end{array}$ \\
\hline $\begin{array}{l}\text { Water } \\
\text { yield } \\
\left(\mathrm{m}^{3} / \mathrm{ha}\right)\end{array}$ & $\begin{array}{l}\text { Water } \\
\text { yield } \\
\text { (mlha) }\end{array}$ & $\begin{array}{c}\text { Water } \\
\text { yield } \\
\left(\mathrm{m}^{3} / \mathrm{ha}\right)\end{array}$ & $\begin{array}{c}\text { Water } \\
\text { yield } \\
\text { (m³/ha) }\end{array}$ \\
\hline 63.21 & 1421.73 & 668.89 & 1051.02 \\
\hline 189.65 & 1434.78 & 710.70 & 1081.63 \\
\hline 356.32 & 1443.47 & 752.50 & 1112.24 \\
\hline 528.73 & 1452.17 & 710.70 & 1132.65 \\
\hline 655.17 & - & - & - \\
\hline 752.87 & - & - & - \\
\hline 833.33 & - & - & - \\
\hline 913.79 & - & - & - \\
\hline 982.75 & - & - & - \\
\hline 1034.48 & - & - & - \\
\hline 1086.20 & - & - & - \\
\hline 1137.93 & - & - & - \\
\hline
\end{tabular}
selected sites

Source: Hosking et al., 2002).

Tsitsikamma, Kouga and Port Elizabeth Driftsands sites have a 4-year fire cycle.

all initial clearing operations of the entire area have been carried out (the study sites are divided into management units which means the incremental water yield increases proportionally annually as more units are cleared for the first time.)

\section{The value of water}

The water yielded at the six Working for Water projects in the Eastern and Southern Cape was priced in terms of relative scarcity. Two pricing methods were employed, namely marginal cost pricing (where water saved through the Working for Water Programme is to be used for urban demand) and a willingness-to-pay approach (where additional water is generated for agriculture).

The marginal cost price of river water is defined as the cost of getting an additional cubic metre of water to a point of demand where it is purchased by bulk buyers, mainly local authorities and agricultural associations. The rationale for using per unit costs as the price of water generated through Working for Water projects is that this is what additional water would otherwise cost. To find a marginal cost price (or unit reference value) an alternative type project should be found, one which generates additional water supply, and preferably an equivalent amount of water.

Agricultural willingness-to-pay prices for water are typically estimated from the difference between the value of land under irrigation (less the value of improvements to make the land suitable for irrigation) and that under use for dry (livestock) farming. This approach is known as income capitalisation. The approach is summarised in the two equations below:

$$
\mathrm{WR}=\frac{\left(\mathrm{W}_{1}-\mathrm{M}-\mathrm{W}_{2}\right)}{\mathrm{Q}} \text { and } \mathrm{W}_{1}=
$$


where:

$\mathrm{WR}=$ the capitalised current $\mathrm{m}^{3}$ water right value in rands

$\mathrm{W}_{1}=$ the value of irrigation land per hectare

$\mathrm{M}=$ the cost of improvements to irrigated land per hectare

$\mathrm{W}_{2}=$ the cost of dry land per hectare

$\mathrm{Q}=$ the $\mathrm{m}^{3}$ of water allocation per hectare

I = the net annual income that is generated through irrigation and crop production per hectare, minus interest on operating capital and depreciation

$=$ the private opportunity cost rate of money income (Hosking and Du Preez, 2002).

The runoff produced by the Tsitsikamma mountain catchment that does not flow into the sea is mainly used for agricultural purposes as a limited amount of water is abstracted by informal settlements. Using the income capitalisation method it was calculated that farmers were willing to pay up to an average of R0.125/ $\mathrm{m}^{3}$ for water, excluding storage and transfer costs (Hosking and Du Preez, 2002).

The Working for Water Programme in the upper reaches of the Keurbooms River in the Tsitsikamma area has a positive impact on the Keurbooms/Bitou estuarine system due to the fact that the Programme ensures that adequate freshwater supplies flow into the estuary keeping the mouth open. Adequate freshwater inflows and hence an open river mouth prevents the loss of environmental services provided by the estuary.

This benefit is captured in the cost-benefit analysis through applying the contingent valuation method in deriving a value per cubic metre for the freshwater that flows into the Keurbooms/Bitou Estuary. The "environmental" value of water is then used to calculate the rand benefit of increased water yield due to the actions of the Working for Water Programme in the Tsitsikamma area. The value of freshwater for the Keurbooms/Bitou Estuary was estimated at R0.046/ $\mathrm{m}^{3}$. Two sets of decision-making criteria (NPV, IRR and BCR - Table 10) were calculated for the Tsitsikamma area: one set where the willingness-to-pay value for water was used to value primary benefit (increased water yield) and another where the environmental value of water (calculated using the contingent valuation method) is used to value the primary benefit.

Three main dams store water inflows from the Kouga and Krom River mountain catchments: the Churchill and Mpofu Dams on the Krom River and the Kouga Dam on the Kouga River. These dams form the main water supply source for the Algoa Bay region, including the Nelson Mandela Metropole. Marginal cost pricing was thus deemed appropriate for valuing water generated by the Kouga Working for Water project.

The marginal cost (unit reference value) of a new water development scheme, namely the Tsitsikamma scheme, was used to value the water yielded by the Kouga Working for Water project (Hosking and Du Preez, 2002). This value is $\mathrm{R} 0.74 / \mathrm{m}^{3}$. The Tsitsikamma scheme entails the capture of runoff from the seaward side of the Tsitsikamma mountain catchment and piping it to the Kouga/Krom water supply system. This is an alternative watersupply creating project and would supply approximately the same amount of water as the Working for Water project (Hosking and Du Preez, 1999).

The Working for Water project in the Port Elizabeth Driftsands area focuses on the removal of alien vegetation where it is believed that a sustainable groundwater resource (aquifer) exists. In terms of yield and water quality this aquifer, however, is not a potential source of municipal supply. It was deduced that water added to the aquifer through water conservation projects in the area has a zero value (Hosking and Du Preez, 2002).

The additional water produced in the Kowie mountain catchment situated in the Albany area due to the Working for Water project is mainly used for agricultural purposes. There is, however, no water rights market in this region and almost no information on specific irrigation land prices (the water has a high salinity content and is unsuitable for irrigation) (Hosking and Du Preez, 2002). For this reason no estimate of the willingness-to-pay value could be made. The Albany project does yield value as a freshwater inflow into the Kowie Estuary. The estuary provides many recreational activities. This value was not estimated directly, but indirectly. The estuary service benefit of freshwater inflow into the Keurbooms Estuary was used $\left(\mathrm{R} 0.046 / \mathrm{m}^{3}\right)$ as a measure of this benefit (the contingent valuation method was employed to determine the value of freshwater inflows into the Keurbooms Estuary.) (Hosking et al., 2002).

The water generated through the Kat River Working for Water project is mainly used by citrus farmers. This water was valued in terms of the willingness-to-pay approach by calculating land value differences using the income capitalisation method. This value was estimated at R0.1575/ $\mathrm{m}^{3}$ of water (Hosking and Du Preez, 2002).

Most of the water generated through the Working for Water project in the Pott River catchment flows into the Umzimvubu River and from there into the sea. The water generated is not a scarce resource from either urban or agricultural perspectives. The Umzimbuvu Estuary is not used as heavily as the Keurbooms or Kowie Rivers. It was thus concluded that the price of water in the Pott River area was zero (Hosking and Du Preez, 2002).

The values derived are shown in Table 4 .

\begin{tabular}{|c|c|c|}
\hline \multicolumn{3}{|c|}{$\begin{array}{c}\text { TABLE } 4 \\
\text { Values of water for Working for Water projects } \\
\text { in the Eastern Cape Province }\end{array}$} \\
\hline Site & $\begin{array}{l}\text { Value of } \\
\text { water } \\
\left(\mathrm{c} / \mathrm{m}^{3}\right)\end{array}$ & Type of value \\
\hline Tsitsikamma & 12.5 & Willingness-to-pay \\
\hline Kouga & 74 & Marginal cost \\
\hline $\begin{array}{l}\text { Port Elizabeth } \\
\text { Driftsands }\end{array}$ & 0 & Potential user response \\
\hline Albany & 4.6 & Environmental opportunity cost \\
\hline Kat River & 15.7 & Willingness-to-pay \\
\hline Pott River & 0 & Non-scarce resource \\
\hline
\end{tabular}

The water yield benefit (R/ha) per fire cycle for the six selected project sites are shown in Table 5.

\section{Secondary benefit estimates}

Only one of the secondary benefits described above was measured and captured in the CBA: increased yield of agricultural products. The form of this benefit was in increased livestock holding capacity.

The net agricultural livestock benefit of the Working for Water Programme at the six project sites was estimated by subtracting livestock farming profit potential with infestation from the profit potential without infestation. The respective profit potentials were calculated using the Department of Agriculture's Enterprise Budget 


\begin{tabular}{|c|c|c|c|c|c|c|}
\hline \multicolumn{7}{|c|}{$\begin{array}{l}\text { TABLE } 5 \\
\text { The water yield benefit (R/ha) per fire cycle for the six selected } \\
\text { sites }\end{array}$} \\
\hline $\begin{array}{l}\text { Fire } \\
\text { cycle } \\
\text { (years) }\end{array}$ & $\begin{array}{l}\text { Tsitsi- } \\
\text { kamma } \\
\text { (R/ha) }\end{array}$ & $\begin{array}{l}\text { Kouga } \\
\text { (R/ha) }\end{array}$ & $\begin{array}{c}\text { Port } \\
\text { Elizabeth } \\
\text { Drift- } \\
\text { sands } \\
\text { (R/ha) }\end{array}$ & $\begin{array}{l}\text { Albany } \\
\text { (R/ha) }\end{array}$ & $\begin{array}{l}\text { Kat } \\
\text { River } \\
\text { (R/ha) }\end{array}$ & $\begin{array}{l}\text { Pott } \\
\text { River } \\
\text { (R/ha) }\end{array}$ \\
\hline 1 & 4.02 & 5.35 & 0 & 65.39 & 105.01 & 0 \\
\hline 2 & 12.08 & 16.08 & 0 & 65.99 & 111.57 & 0 \\
\hline 3 & 26.14 & 39.16 & 0 & 66.39 & 118.14 & 0 \\
\hline 4 & 33.48 & 74.61 & 0 & 66.79 & 111.57 & 0 \\
\hline 5 & 50.18 & 108.18 & 0 & - & - & - \\
\hline 6 & 63.77 & 139.20 & 0 & - & - & - \\
\hline 7 & 75.36 & 169.51 & 0 & - & - & - \\
\hline 8 & 85.56 & 199.82 & 0 & - & - & - \\
\hline 9 & 94.78 & 230.60 & 0 & - & - & - \\
\hline 10 & 103.22 & 262.78 & 0 & - & - & - \\
\hline 11 & 111.03 & 296.36 & 0 & - & - & - \\
\hline 12 & 118.41 & 331.80 & 0 & - & - & - \\
\hline
\end{tabular}

for 2001. The annual profit potentials were estimated by multiplying the net profit (margin above cost) per large stock unit by the carrying capacity and the amount of hectares cleared in every area. The net profit (margin above cost) per large stock unit was estimated as the difference between total gross income and purchases, plus directly allocatable costs. The total gross income was that derived from the product of the weight of a large stock unit and the income per kilogram. The directly allocatable costs included marketing, transportation, medicine, lick and feed, self-produced grazing per cow, and the gestation examination.

Fixed costs(such as fencing) were not included in the calculations because they were deemed to be sunk costs(a sunk cost is one that was incurred in the past that cannot be recaptured as a residual value from an earlier investment). Where fynbos was the indigenous vegetation, no additional grazing benefit could be determined. The increased agricultural yield benefits for project sites are shown in Table 6.

\section{The social discount rate}

The social discount rate (i) used in this analysis was determined by reference to the sources of funding for the Working for Water Programme during the period 1996 to 2000.

The three main sources of funds for the Working for Water Programme from 1996 to 2000 were taxes, government borrowing and foreign aid. Tax funding requires consumption and savings to be sacrificed by households and companies. The cost of the consumption sacrificed was measured by the interest rates consumers are prepared to pay to borrow ( $\mathrm{x}_{1}$ in Eq. (1)). The saving sacrificed was measured by foregone dividend yield and capital growth on their savings ( $\mathrm{x}_{2}$ in Eq. (1)). Government borrowing also has a cost - the rate of interest paid on government bonds $\left(\mathrm{x}_{3}\right.$ in Eq. (1)). Foreign aid does not carry any opportunity cost from the South African perspective unless the money would have been allocated elsewhere in the country. For this reason the interest rate cost of foreign funding ( $\mathrm{x}_{4}$ in Eq. (1)) was set equal to zero.
The formula by which these sources were combined is shown in Eq. (1) below:

$$
i=(1-f) t\left[(1-s)\left(x_{1}-p\right)+(s)\left(x_{2}-p\right)\right]+(1-f)(1-t)\left(x_{3}-p\right)+f\left(x_{4}-p\right)
$$

where:

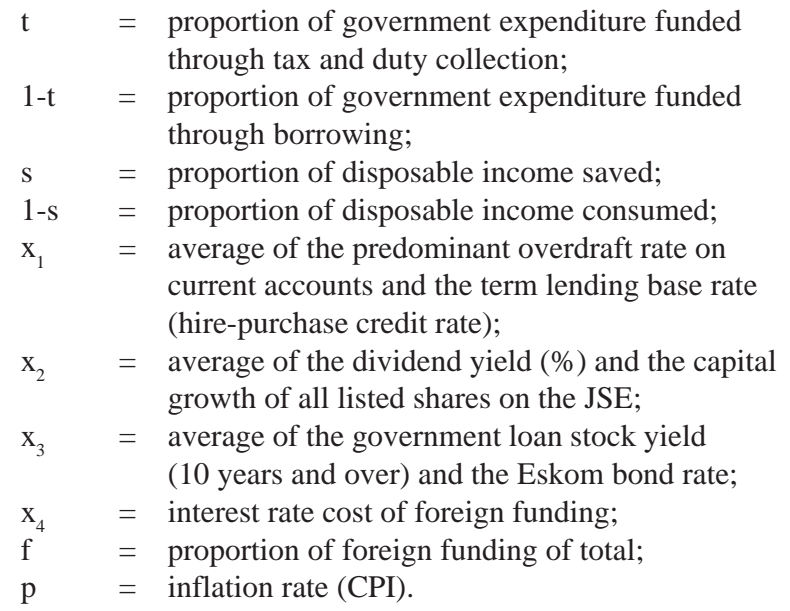

The data used to calculate the social discount rate (Eq. (1)) are shown in Tables 7, 8 and 9. Table 7 shows the cost of government borrowing, the cost of household consumption borrowing, the return on savings and the annual inflation rate for the period 1996 to 2000. Table 8 shows the calculation of tax and borrowing weights, and Table 9 shows the calculation of saving and consuming weights.

Over the five year period (1996 to 2000) the proportion of foreign funding of the total funds procured by the Working for Water Programme averaged 1\% (see f, Eq. (1)) (Versveld et al., 1998).

In terms of Eq. (1) and the information provided in Tables 7, 8 and 9 the discount rate for the Working for Water Programme was 
TABLE 7

Cost of government borrowing, cost of household consumption borrowing, the return on savings and the annual inflation rate (1996-2000)

\begin{tabular}{|c|c|c|c|c|c|c|c|c|c|c|}
\hline \multirow[t]{2}{*}{ Year } & \multicolumn{3}{|c|}{ Cost of government borrowing } & \multicolumn{3}{|c|}{$\begin{array}{l}\text { Cost of household } \\
\text { consumption borrowing }\end{array}$} & \multicolumn{3}{|c|}{ Return on savings } & \multirow{2}{*}{$\begin{array}{c}\text { Average } \\
\text { annual } \\
\text { inflation rate } \\
\text { as measured } \\
\text { by consumer } \\
\text { price index\% }\end{array}$} \\
\hline & $\begin{array}{l}\text { Govern- } \\
\text { ment } \\
\text { stock - } \\
\text { yields } \\
\text { on loan } \\
\text { stock } \\
\text { traded } \\
\text { on the } \\
\text { bond } \\
\text { exchange } \\
\text { (10 years } \\
\text { and over), } \\
\% \text { (a) }\end{array}$ & $\begin{array}{l}\text { Eskom } \\
\text { Bond } \\
\text { Yield, } \\
\% \text { (b) }\end{array}$ & $\begin{array}{c}\begin{array}{c}\text { Average } \\
\text { Yield, \% } \\
(\mathrm{a})+(\mathrm{b}) \\
2 \\
\mathrm{x}_{3}\end{array}\end{array}$ & $\begin{array}{c}\text { Pre- } \\
\text { dominant } \\
\text { overdraft } \\
\text { rate on } \\
\text { current } \\
\text { accounts, } \\
\% \text { (c) }\end{array}$ & $\begin{array}{l}\text { Long- } \\
\text { term } \\
\text { lending } \\
\text { base } \\
\text { rate (Hire - } \\
\text { purchase } \\
\text { credit), } \\
\% \text { (d) }\end{array}$ & $\begin{array}{c}\begin{array}{c}\text { Average } \\
\text { rate, } \%\end{array} \\
\frac{(\mathrm{c})+(\mathrm{d})}{2} \\
\mathrm{x}_{1}\end{array}$ & $\begin{array}{l}\text { Dividend* } \\
\text { yield } \\
\%(e)\end{array}$ & $\begin{array}{c}\text { Capital } \\
\text { growth } \\
\% \text { (f) }\end{array}$ & $\begin{array}{l}\text { Average \% } \\
\begin{array}{c}\frac{(\mathrm{e})+(\mathrm{f})}{2} \\
\mathrm{x}_{2}\end{array}\end{array}$ & \\
\hline 1996 & 16.19 & 16.16 & 16.18 & 22.5 & 19.8 & 21.15 & 2.25 & 21 & 11.63 & 7.4 \\
\hline 1997 & 14.14 & 14.19 & 14.17 & 22 & 19.25 & 20.63 & 2.45 & 3.3 & 2.88 & 8.6 \\
\hline 1998 & 16.36 & 16.78 & 16.57 & 22.64 & 22.36 & 22.5 & 2.71 & -5.6 & -1.45 & 6.9 \\
\hline 1999 & 13.96 & 14.45 & 14.21 & 18.10 & 18.69 & 18.4 & 2.62 & 5.9 & 4.3 & 5.2 \\
\hline 2000 & 12.88 & 13.23 & 13.06 & 14.83 & 14.5 & 14.67 & 2.45 & 15.2 & 8.83 & 5.3 \\
\hline
\end{tabular}

(Sources: $\quad$ SARB Quarterly Bulletin, 1998; 1999; 2000

Statistics South Africa, July 2001)

\begin{tabular}{|c|c|c|c|c|c|}
\hline \multicolumn{6}{|c|}{$\begin{array}{c}\text { TABLE } 8 \\
\text { The calculation of discount rate weights - }(t) \text { and (1-t) }\end{array}$} \\
\hline Year & $\begin{array}{l}\text { Govern- } \\
\text { ment } \\
\text { borrow- } \\
\text { ing } \\
\text { require- } \\
\text { ment } \\
\text { R millions } \\
\text { (a) }\end{array}$ & $\begin{array}{c}\text { Govern- } \\
\text { ment } \\
\text { revenue } \\
\mathrm{R} \text { millions } \\
\text { (b) }\end{array}$ & $\begin{array}{c}\text { Total } \\
\text { R millions } \\
\text { (c) }=(\mathbf{a})+(\mathbf{b})\end{array}$ & $\begin{array}{l}\begin{array}{c}\text { Borrow- } \\
\text { ing } \\
\text { propor- } \\
\text { tion } \\
\frac{(a)}{(c)} \\
(1-\mathrm{t})\end{array}\end{array}$ & $\begin{array}{c}\text { Tax } \\
\text { revenue } \\
\text { proportion } \\
\frac{(b)}{(c)} \\
(t)\end{array}$ \\
\hline 1996 & 29001 & 127109 & 156110 & 0.19 & 0.81 \\
\hline 1997 & 31501 & 145999 & 177500 & 0.18 & 0.82 \\
\hline 1998 & 25764 & 163921 & 189684 & 0.14 & 0.86 \\
\hline 1999 & 20862 & 183166 & 204028 & 0.10 & 0.90 \\
\hline 2000 & 19025 & 197380 & 216405 & 0.09 & 0.91 \\
\hline
\end{tabular}

(Source: SARB Quarterly Bulletin (1998; 1999; 2000).

10.1\%/a. In a critique of the analysis it has been argued that the rate used was too high because some agricultural projects in South Africa used a discount rate of $5 \%$, and that this lower rate was also used to calculate the pension payment to members of the AIP fund in 1995 (Antoinites, 2002). It was not possible to establish the relevance of these other project decisions to the one assessed here. However, what emerged from the inquiry was divergent views on the discount rates appropriate to this project (and indeed other environmental projects in South Africa). However, it was attempted to incorporate the alternative views by subjecting the results to a sensitivity analysis with respect to the discount rate.

\begin{tabular}{|c|c|c|c|c|c|}
\hline \multicolumn{6}{|c|}{$\begin{array}{c}\text { TABLE } 9 \\
\text { The calculation of discount rate weights - } \\
\text { (s) and }(1-\mathrm{s})\end{array}$} \\
\hline Year & $\begin{array}{c}\text { Final } \\
\text { consump- } \\
\text { tion } \\
\text { expendi- } \\
\text { ture } \\
\text { R million } \\
\text { (a) }\end{array}$ & $\begin{array}{l}\text { Gross } \\
\text { savings } \\
\text { R million } \\
\text { (b) }\end{array}$ & $\begin{array}{l}\text { Gross } \\
\text { national } \\
\text { disposable } \\
\text { income } \\
\text { (c) }=(a)+(b)\end{array}$ & 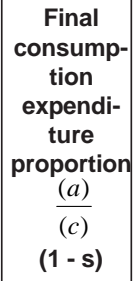 & $\begin{array}{c}\text { Gross } \\
\text { savings } \\
\text { proportion } \\
\frac{(b)}{(c)} \\
(s)\end{array}$ \\
\hline 1996 & 505419 & 97732 & 603149 & 0.84 & 0.16 \\
\hline 1997 & 566671 & 99074 & 665744 & 0.85 & 0.15 \\
\hline 1998 & 612480 & 105015 & 717495 & 0.85 & 0.15 \\
\hline 1999 & 657568 & 116498 & 774066 & 0.85 & 0.15 \\
\hline 2000 & 716458 & 132541 & 848999 & 0.84 & 0.16 \\
\hline
\end{tabular}

\section{Results}

When the above estimates of costs, benefits and the discount rate were incorporated into the formulae of the NPV, IRR and BCR decision-making criteria, the results in Table 10 were obtained.

For all the Working for Water projects assessed in this study (at a real social discount rate of $10.1 \%$ ), the NPVs were less than zero, the BCRs were less than one and the IRRs were less than the social discount rate. When the water benefit in the Tsitsikamma case is 


\begin{tabular}{|c|c|c|c|}
\hline \multicolumn{4}{|c|}{$\begin{array}{c}\text { TABLE } 10 \\
\text { Summary of results }\end{array}$} \\
\hline \multirow[b]{2}{*}{ Project } & \multicolumn{3}{|c|}{ CBA criteria } \\
\hline & NPV (R) & IRR (\%) & BCR \\
\hline Tsitsikamma (agricultural water value) & -31757404 & 5.00 & 0.54 \\
\hline (estuarine water value) & -55492203 & 1.20 & 0.20 \\
\hline Kouga & -33854196 & 7.25 & 0.75 \\
\hline Port Elizabeth Driftsands & -14674240 & 0 & 0 \\
\hline Albany & -15232753 & 1.13 & 0.21 \\
\hline Kat River & -1031609 & 3.60 & 0.43 \\
\hline Pott River & -1446624 & -3.14 & 0.03 \\
\hline
\end{tabular}

\begin{tabular}{|l|c|c|c|}
\hline \multicolumn{3}{|c|}{ TABLE 11 } \\
\multicolumn{4}{|c|}{ Sensitivity analysis results } \\
\hline \multirow{2}{*}{ Project } & Criterion & \multicolumn{2}{c|}{ Discount rate } \\
\cline { 3 - 4 } & & $8.1 \%$ & $5.1 \%$ \\
\hline \multirow{2}{*}{ Kouga } & NPV (R) & -15029416 & 78304839 \\
Tsitsikamma (agricultural water value) & NPV (R) & -27712341 & -1100502 \\
& BCR & 0.65 & 0.98 \\
Port Elizabeth Driftsands & NPV (R) & -16942817 & -21491714 \\
Albany & BCR & 0 & 0 \\
Kat River & NPV (R) & -16698118 & -17887841 \\
& BCR & 0.26 & 0.38 \\
Pott River & NPV (R) & -1003887 & -638843 \\
Tsitsikamma (estuarine water value) & BCR & 0.51 & 0.75 \\
& NPV (R) & -1542548 & -1706982 \\
& NPV (R) & -61405091 & -66842173 \\
& BCR & 0.24 & 0.36 \\
\hline
\end{tabular}

increased levels of productivity and improvements in management efficiency).

\section{The social discount rate}

The analysis was conducted by assigning two different values to the social discount rate, namely $8.1 \%$ and $5.1 \%$. The results are shown in Table 11.

As can be seen from Table 11 it makes no difference whether $8.1 \%$ or $5.1 \%$ is used, when the NPV and BCR criteria are applied to decide on the Tsitsikamma (water benefit valued at the estuarine value or water benefit valued at the agricultural value), Port Elizabeth Driftsands, Albany, Kat River and Pott River projects. None of these projects are efficient. With the Kouga project the results shown above indicate that varying the discount rate has an effect on the outcome of the evaluation; the abovementioned project becomes desirable when a social discount rate of $5.1 \%$ is used. The NPV is positive and the BCR is greater than one. On the other hand, if a higher discount rate is used (8.1\%) it is not desirable that the project proceed, because the NPV is negative and the BCR is smaller than one. For this reason it is deduced that the case for this project is qualified, based on the social discount rate not rising above $5.1 \%$.

\section{Productivity of clearing teams and management efficiency}

It has been argued by Van Wilgen (2002) that the increased productivity of clearing teams, due to learning by doing, would significantly reduce clearing costs. Marais (1998) maintained that the productivity valued at the estuarine value, the NPV is less than zero, the BCR is less than one and the IRR is less than the social discount rate.

If the project (Working for Water Programme) is redefined as the sum of all of the subprojects, the cost-benefit analysis criteria are negative for this summed project. For the gross regional project the NPV is -R97 996826 and the BCR is 0.59.

\section{Sensitivity analysis}

It is frequently not known what the environmental repercussions of undertaking a specific policy or project will be. The framework of much environmental policy is typified by uncertainty concerning the effect and irreversibility of some effects.

The explicit difference between risk and uncertainty is that risk refers to situations where the nature of the probability distribution of future events is known, while uncertainty refers to situations where the probabilities are unknown.

The problem of uncertainty in cost-benefit analysis may be addressed, to some extent, through sensitivity analysis. This type of analysis shows the variation in the measure of project worth, for example NPV, IRR and BCR, as changes are made to the values of particular variables.

A limited sensitivity analysis was carried out in this study to determine the effects on the above-mentioned measures of project worth of varying the social discount rate and cost estimates (due to of clearing teams increased substantially, subsequent to the introduction of the Piece-Work System where financial incentives to produce were built in. According to Marais (1998) a 20\% increase in productivity levels could easily be achieved. Moreover, Marais (1998) showed that an increase in productivity of $40 \%$ would lead to a doubling of total NPV for clearing programmes in the inland catchments of the Western Cape.

As far as improvements in management efficiency are concerned, Marais (1998) showed that an increase of 3.1\% in NPV for every $1 \%$ increase in management efficiency could be achieved. It should be noted that the majority of the clearing costs are incurred at the beginning of the project period and that the benefits accrue over the entire project period. Reductions in the cost of clearing at the beginning of the project period would have a major impact on the economic feasibility of the clearing programme over the long term.

In this study it was decided to examine what the impacts on the results of reducing clearing costs by $10 \%, 20 \%$ and $30 \%$, as suggested by Van Wilgen (2002), on the grounds that this could be achieved through increases in productivity levels of clearing teams and improvements in management efficiency. The results of this sensitivity analysis are shown in Table 12 .

It can be seen from Table 12 that increases in clearing productivity and improvements in management efficiency, which lead to clearing cost reductions, would only have a significant impact on 


\begin{tabular}{|c|c|c|c|}
\hline \multicolumn{4}{|c|}{$\begin{array}{c}\text { TABLE } 12 \\
\begin{array}{l}\text { Sensitivity analysis of the effect of improvements in } \\
\text { productivity/management efficiency }\end{array}\end{array}$} \\
\hline \multirow[t]{2}{*}{ Site } & \multicolumn{3}{|c|}{$\begin{array}{l}10 \% \text { clearing cost } \\
\text { reduction } \\
\text { decision-making } \\
\text { criteria }(\mathbf{1 0 . 1 \% )}\end{array}$} \\
\hline & NPV & IRR & BCR \\
\hline Kouga & -20508422 & 8.20 & 0.83 \\
\hline Tsitsikamma & -24826157 & 5.70 & 0.60 \\
\hline Port Elizabeth Driftsands & -13206816 & 0 & 0 \\
\hline Albany & -13294830 & 1.44 & 0.24 \\
\hline Kat River & -851793 & 4.10 & 0.47 \\
\hline Pott River & -1298392 & -2.99 & 0.02 \\
\hline \multirow[t]{2}{*}{ Site } & \multicolumn{3}{|c|}{$\begin{array}{l}20 \% \text { clearing cost } \\
\text { reduction } \\
\text { decision-making } \\
\text { criteria }(10.1 \%)\end{array}$} \\
\hline & NPV & IRR & BCR \\
\hline Kouga & -7162647 & 9.32 & 0.93 \\
\hline Tsitsikamma & -17894911 & 6.50 & 0.68 \\
\hline Port Elizabeth Driftsands & -11739392 & 0 & 0 \\
\hline Albany & -11356906 & 1.80 & 0.27 \\
\hline Kat River & -671978 & 4.70 & 0.53 \\
\hline Pott River & -1150527 & -2.83 & 0.03 \\
\hline \multirow[t]{2}{*}{ Site } & \multicolumn{3}{|c|}{$\begin{array}{l}30 \% \text { clearing cost } \\
\text { reduction } \\
\text { decision-making } \\
\text { criteria }(10.1 \%)\end{array}$} \\
\hline & NPV & IRR & BCR \\
\hline Kouga & 6183126 & 10.90 & 1.07 \\
\hline Tsitsikamma & -10963664 & 7.60 & 0.77 \\
\hline Port Elizabeth Driftsands & -10271968 & 0 & 0 \\
\hline Albany & -9418982 & 2.24 & 0.31 \\
\hline Kat River & -492163 & 5.60 & 0.61 \\
\hline Pott River & -1002662 & -2.63 & 0.03 \\
\hline
\end{tabular}

the Kouga project. For a 30\% clearing cost reduction scenario the NPV is greater than zero, the IRR exceeds the social discount rate (10.1\%) and the BCR is greater than one. No marked changes could be observed for the other sites.

It should, however, be noted that the Kouga project becomes favourable with $10 \%$ and $20 \%$ clearing cost reductions if a social discount rate of $8.1 \%$ (instead of $10.0 \%$ ) is employed - the IRRs (8.20\% and 9.32\%) exceed the lower discount rate. The case for the Kouga project is qualified, based on the social discount rate not rising about $8.1 \%$ and that the clearing cost reductions, due to increases in productivity and improvements in management efficiency, are realised. According to Buckle (2002) the number of person days required to clear 1 ha in the Kouga project, decreased from $40 \mathrm{~d}$ in 1999 to $22 \mathrm{~d}$ in 2002. This has been due mainly to learning by doing and suggests that clearing cost reductions up to $30 \%$ could be achieved.

The same case could be made for the Tsitsikamma project. The feasibility of this project is, however, dependent on the social discount rate being $5.1 \%$ and clearing cost reductions of $10 \%$ or more being realised.

\section{Conclusion and recommendations}

The authors are inclined to want conservation projects to go ahead and still feel this way about South Africa's Working for Water Programme. However, the cost-benefit analysis of six sites in the Eastern and Southern Cape only provides qualified efficiency support. At all six sites investigated: the Tsitsikamma, Kouga, Port Elizabeth Driftsands, Albany, Kat River and Pott River sites, none were efficient in terms of streamflow and livestock-carrying capacity gains, at what the study estimated to be the relevant discount rate.

The NPVs were less than zero, the BCRs were less than one and the IRRs were less than zero. However, it is very important to note that this conclusion is subject to three qualifications. The first is that more work remains to be done on the evaluation of the other non-water benefits, like fire damage reduction and preservation of biodiversity. The second qualification is that at lower discount rates, for instance $5 \%$, the Kouga project is efficient. The third qualification is that if $30 \%$ cost savings could be achieved and a discount rate of $5 \%$ be employed that both the projects on the Kouga and Tsitsikamma sites would be efficient. These two projects are being run in catchments which serve areas where high consumptive demand exists. The Working for Water Programme at the other four sites remains inefficient even after these adjustments, and consideration would have to be given as to whether other reasons are sufficient to outweigh these negative results, e.g. poverty alleviation and biodiversity.

\section{Acknowledgements}

Support for this research by the Water Research Commission (WRC) and discussions and contributions from Dr G Backeberg (WRC) are gratefully acknowledged.

\section{References}

ANTOINITES T (2002) Referees report on submission of a paper to the SAJE in which this discount rate was used.

BRIERS HJ and POWELL M (1993) The Effect of Invader Plants: Acacia Mearsnii (Black Wattle) in the Kouga and Krom River Catchments. Algoa Water Resources System Analysis, Port Elizabeth.

BUCKLE JD (1999) Personal communication. Manager - Working for Water Programme, Port Elizabeth.

BUCKLE JD (2002) Personal communication. Manager - Working for Water Programme, Port Elizabeth.

CHAPMAN RA, SCOTT DF and LE MAITRE DC (1995) Hydrological impacts of aliens in fynbos catchments. In: Boucher $\mathrm{C}$ et al. (eds.) Managing Fynbos Catchments for Water. Foundation for Research Development.Pretoria. 40-43.

DEPARTMENT OF WATER AFFAIRS AND FORESTRY (1999) Regional Implementation Strategy for the Working for Water Program. DWAF, King William's Town.

DU PLESSIS LL (2002) Valuation procedures for selected non-water benefits of the Working for Water Programme. Paper presented at FEE Conference, Cape Town.

GILLHAM S and HAYNES M (2001) Evaluating a riparian clearing programme as a water management strategy. Unpublished paper presented at the $10^{\text {th }}$ South African National Hydrology Symposium, Pietermaritzburg. 26-28 September.

HOSKING SG and DU PREEZ M (1999) A cost benefit analysis of removing alien trees in the Tsitsikamma mountain catchment. S. Afr. J. Sci. 95 442-448.

HOSKING SG and DU PREEZ M (2002) Valuing water gains in the Eastern Cape's Working for Water Programme. Water SA 28 (1) 23-28. 
HOSKING SG, DU PREEZ M, CAMPBELL EE, WOOLDRIDGE TH and DU PLESSIS LL (2002) Evaluating The Environmental Use of Water - Selected Case Studies in the Eastern and Southern Cape. Water Research Commission Report No 1045/0/1.

LE MAITRE DC, VAN WILGEN BW, CHAPMAN RA and MCKELLY DH (1996) Invasive plants in the Western Cape, South Africa: Modelling the consequences of a lack of management. J. Appl. Ecol. 33161 - 172.

MARAIS C (1998) An Economic Evaluation of Invasive Alien Plant Control Programmes in the Mountain Catchment Areas of the Western Cape Province, South Africa. Unpublished Ph.D. Thesis, University of Stellenbosch.

SOUTH AFRICAN RESERVE BANK(SARB) (1998; 1999; 2000) Quarterly Bulletin. December 1998, September 1999 and September 2000.

STATISTICS SOUTH AFRICA (2001) Economic indicators. www.statssa.gov.za/Economic\% 20Indicators/CPI.htm. (July 2001).
VAN WILGEN BW (2002) Personal communication. CSIR, Cape Town. VAN WILGEN BW, COWLING RM and BURGERS CJ (1996) Valuation of ecosystem services. Biosci. 46 (3) 184-189.

VAN WILGEN BW, LITTLE PR, CHAPMAN RA, GÖRGENS AHM, WILLEMS T and MARAIS C (1997) The sustainable development of water resources: history, financial costs, and benefits of alien plant control programmes. S. Afr. J. Sci. 93 404-411.

VAN WILGEN BW, TROLLOPE WSW and EVERSON CS (1990) Fire management in Southern Africa: Some examples of current objectives, practices and problems. In: Goldammer JC (ed.) Fire in the Tropical Biota: Ecosystem Processes and Global Challenges. Springer-Verlag, Berlin, Germany.

VERSVELD DB, LE MAITRE DC and CHAPMAN RA (1998) Alien invading plants and water resources in South Africa: A preliminary assessment.CSIR Division of Water,Environment and Forest Technology.Stellenbosch. 